\title{
On Negative Eventualities, Negative Concord, and Negative Yes/No Questions
}

\author{
Adam Przepiórkowski \\ Polish Academy of Sciences and University of Tübingen
}

The general aim of this paper is to argue for the existence and linguistic importance of a so far controversial subclass of eventualities, i.e., negative eventualities.

The paper is divided into three parts. First, it shows that arguments which led to the acceptance of event(ualitie)s as first-class semantic objects apply also to negative eventualities. Second, it argues that negative eventualities play the licensing role in Negative Concord. Third, it provides evidence from negative yes/no questions for the claim that natural language negation is ambiguous between propositional and eventuality negation meanings. Although these considerations are compatible with a number of semantic frameworks, a Situation Semantics analysis of the third part is sketched.

\section{Negative Eventualities as First-Class Linguistic Entities}

It is occasionally questioned whether negated clauses, negated gerundial phrases, etc., can assert existence of eventualities, i.e., whether negative eventualities (NEs) exist. In this part, I will first present various arguments, most collected from the literature, other new, for the claim that NEs should be accepted as first-class semantic entities, and then I will consider possible objections to this stance.

\subsection{Arguments for the Existence of Negative Eventualities}

The arguments for the existence of NEs below are given roughly in the increasing order of strength.

\section{Anaphoric Reference}

The first argument for NEs, adduced, e.g., by de Swart 1996, comes from the possibility of anaphoric reference to entities introduced by negated clauses:

(1) John did not ask Mary to dance at the party. It made her angry.

(2) John didn't know the answer to the problem. This lasted until the teacher did the solution on the board.

However, this argument is considerably weakened by the fact that, as extensively discussed by Asher 1993, anaphors may also refer to propositions and facts. ${ }^{1}$

(3) Susan's boyfriend has graduated. But Sally does not believe it. 
(4) He is a brute. His behaviour shows this quite clearly.

Thus, (1)-(2) constitute evidence for negative eventualities only insofar as only eventualities, not propositions or facts, can enter causative relations and can last for a period of time (see below).

Nominal Reference

Higginbotham 1996a, p.45, cites the following data as providing evidence for NEs:

the non-explosion of the gases

the non-rising of the sun

However, it is not immediately clear that whatever such phrases refer to are eventualities.

Since Vendler 1967 and Davidson 1980, it is uncontroversial that deverbal nominals may refer to eventualities and other abstract entities such as propositions. It is much less clear, though, what kinds of deverbal nominals can refer to what kinds of abstract entities. In order to construct an argument for negative eventualities, one needs to find a class of deverbal nominals which can be used exclusively to refer to eventualities, and show that such nominals can be negated.

Asher 1993, §1.1, adopts the following fine-grained taxonomy of deverbal nominal phrases in English:

- ACC-ing gerund phrases, e.g., Fred singing the Marseille;

- POSS-ing gerund phrases, e.g., Fred's giving the book to Mary;

- of-ing gerund phrases, e.g., the mayor's throwing of the pizza in the guest of honour's face;

- derived nominal phrases, e.g., Caesar's destruction of Carthage.

As discussed by Asher 1993, propositional contexts (see endnote 1) may take certain derived nominals, but not of-ing or POSS-ing gerunds, while factual contexts can take POSS-ing gerunds and perhaps also ACC-ing gerunds, but apparently not of-ing gerunds. So, if there is a class of deverbal nominals referring exclusively to eventualities, it is the class of of-ing gerunds.

Unfortunately, of-ing gerunds are morphosyntactically nominal rather than verbal categories (this is shown by the obligatoriness of of) and so they cannot combine with not:

*the not exploding of the gases

On the other hand, as (6) above shows, of-ing gerunds can be modified by non, but since this possibility is restricted and often felt by native speakers as marked, it seems that such examples provide only suggestive evidence for NEs. ${ }^{2}$

\section{Causation}

It is a standard assumption that only event(ualitie)s can be causes and effects 
(Davidson 1980, Thompson 1977, Rosner 1986, Parsons 1990, Higginbotham 1996a). If so, then examples below provide evidence for NEs:

(8) I kept the child awake by not turning out the light. (Higginbotham 1996a)

(9) He didn't stop at the lights because he didn't notice them.

This standard assumption has, however, been questioned by Asher 1993, who notes (p.29) that "facts appear to have causal efficacy":

(10) The fact that John had a headache made him crabby.

(11) John's crabbiness resulted in the fact that everyone avoided him.

Evidence to the similar effect can be found in Parsons 1990, p.160:

(12) John's rude answering of the phone was caused by his fight with his wife.

$\cong$ The fact that John answered in a rude manner was caused by...

$\neq$ The rude phone-answering event was caused by...

Parsons 1990 mentions, though, that such "tendency of certain kinds of causal talk to replace 'event causation' with 'fact causation' is discussed in detail in Bennett $1988 \ldots$, [who] makes it clear how causal talk does not threaten the underlying event theory." Unfortunately, at the time of writing this paper I was not able to access Bennett 1988, so it is not clear to me how strong the evidence based on data such as (8)-(9) eventually is.

\section{Modification by Relative Clauses}

An argument similar to that provided by anaphoric reference, but stronger, as we will presently see, comes from the possibility of an eventuality to be modified by a relative clause. Assuming that eventualities, but not propositions, may enter causal relations (see above), that propositions, but not eventualities, may occur in the $X$ is true context, and that show $X$ is a factual context (Asher 1993), (13)-(15) show that which may refer to eventualities, but not to propositions or facts:

(15) *John kissed Mary, which is shown by her blushed face.

A straightforward analysis of this fact in terms of event semantics is that which represents the event variable introduced by the modified clause. If so, negated clauses also introduce event variables:

(16) John didn't ask Mary to dance at the party, which made her angry. 


\section{Perceptual Reports}

According to various papers by James Higginbotham (e.g., Higginbotham 1983, 1996b) and to Parsons 1990, among others, perception verbs such as see, hear, etc., semantically select event(ualitie)s (syntactically realized as naked infinitive constructions). If so, then examples such as (17), attributed by Does 1991 to Elisabet Engdahl, involve reference to NEs.

(17) The policeman saw Andrew not stop for the traffic light.

I take this to be a relatively strong argument for $\mathrm{NEs}^{3}$

\section{Explicit Quantification}

One of the main strengths of event semantics is that it naturally accounts for inferences such as (18), from Parsons 1990, p.18.

(18) a. In every burning, oxygen is consumed.

b. Agatha burned the wood.

$\therefore$ Oxygen was consumed.

Similar inference patterns are displayed by negated clauses, which shows that they, too, refer to (negative) eventualities:

(19) a. Whenever he doesn't do his homework, he is punished.

b. He won't do his homework today.

$\therefore$ He will be punished.

(20) a. In every not stopping for the traffic light, the law is broken.

b. She didn't stop for the traffic light.

$\therefore$ The law was broken.

Note that, although (20a) may sound slightly deviant, the inference still goes through. The relative marginality of such sentences seems to be of a morphosyntactic nature: there is a clash between the occurrence of not, which suggests the verbality of the gerund, and the presence of every, which suggests that the gerund occurs here in its nominal guise.

No such deviancy is present in Polish, in which gerunds may simultaneously have nominal (e.g., case marking, adjectival modification) and verbal (e.g., aspectual marking, negative affix) characteristics:

(21) a. Każde jego nieodrobienie pracy domowej kończy się ukaraniem go. every his not-doing-PERF work home end Refl punishing him 'His every not doing his homework ends with a punishment.'

b. On nie odrobi dziś pracy domowej. he not do-FUT today work home 'He won't do his homework today.' 
$\therefore$ On będzie ukarany. he be-FUT punished 'He will be punished.'

Adverbs of Quantification

As noted by de Swart 1996, pp.229-230, adverbs of quantification can outscope sentential negation (an observation attributed to Stockwell et al. 1973):

(22) He often hasn't paid taxes.

(23) He sometimes doesn't eat dinner.

If, as often assumed, adverbs of quantification quantify over eventualities only, not over facts or propositions, then such examples provide a strong argument for NEs.

Cardinality Adverbials

A similar argument can be constructed on the basis of cardinality adverbials, which - as claimed, e.g., by Parsons 1990, p.224_quantify over events, not over times, when they occur in a postverbal position. A relevant datum is given below.

(24) In all his life, [John didn't come to a party he was invited to] twice. It was actually on the same evening.

Temporal Adverbials

Again, it is uncontroversial that temporal adverbials can modify only eventualities; facts and prepositions are timeless. If so, then data such as (25)-(26), from Higginbotham 1996a and Asher 1993, respectively, constitute evidence for NEs.

(25) [John didn't play golf] until noon.

(26) [No one talked] for over two hours.

\section{Reference Time}

Within the DRT (Kamp and Reyle 1993) set of assumptions, only events move forward reference time. As examples such as (27), from de Swart and Molendijk 1998, show, eventualities expressed by negated sentences may move forward reference time.

(27). Mary smiled at John. He didn't smile back.

This argument is interesting because it shows that negated sentences may actually express events, not just states or processes, as occasionally claimed (see $§ 1.2){ }^{4}$ 
Answer to What happened?

Since only event(ualitie)s, not other kinds of abstract entities, may happen, data * such as (28) below, from de Swart 1996, provide strong evidence for the existence of NEs.

(28) What happened next was that the consulate didn't give us our visa.

\section{Argument of take place}

Finally, it is a standard assumption that subjects of occur, take place, etc., must be eventualities. Although, in English, this position cannot be easily occupied by a negated gerundial phrase, many native speakers accept (29), and also Polish (30) is impeccable.

(29) His not fulfilling the duties of his position took place over a six-month period in 1983.

(30) Niedopełnienie obowiązków służbowych przez Kowalskiego miało miejsce not-fulfilment-PERF duties professional by Kowalski had place w roku 1983.

in year 1983

'Kowalski's not fulfilling his professional duties took place in 1983.'

Summary

I have shown that there is enough evidence, some of it very strong, to conclude that negated clauses, gerundives, etc., assert the existence of eventualities, just as their non-negated counterparts do. In the remainder of this part, I'll try to address some questions brought forth by this conclusion.

\subsection{Additional Matters}

Restricted Modification Possibilities

One possible objection to the existence of NEs might be that they cannot be easily modified:

*John slowly didn't butter a piece of toast.

*[John didn't butter a piece of toast] with a knife.

Recall that inference patterns shown by such modified clauses played a crucial role in establishing events as first-class linguistic entities (Davidson 1980).

Although I have nothing to say about the reasons of unacceptability of (31)-(32), I believe that this inability of NEs to be modified by manner, instrumental, etc., adverbials does not weaken our conclusion.

First of all, there are other classes of well-established eventualities which 
exhibit very restricted modification possibilities, cf., e.g., the discussion of states in Parsons 1990, pp.189-190.

Second, although NEs cannot be modified by manner adverbials, they can * be modified by various other classes of adverbials. For example, (25)-(26) above are two examples of modification by adverbials of duration, and (33) below is one more telling example, from Polish.

(33) długie niepodpisywanie ustawy doprowadziło do...

long-ADJ not-signing-IMPERF bill led to...

'[[ not signing the bill] for a long time] led to...'

cannot mean: '[not [signing the bill for a long time]] led to...'

See also (i) in endnote 2 for an example of modification by a temporal location adverbial, (34) below for modification by a locative adverbial, and (35) for an attested example of modification by unexpected (all from Polish).

(34) Nieutrzymanie równowagi przez Jelcyna, które miało miejsce w not-keeping-PERF balance by Yeltsin which had place in

Azerbejdżanie...

Azerbaijan...

'Yeltsin's not keeping his balance, which took place in Azerbaijan...'

wczorajsze nieoczekiwane nieuznanie praw Kowalskiego do tej

yesterday-ADJ unexpected not-recognizing-PERF rights Kowalski's to this posesji...

immovable property...

'the [unexpected [not recognizing Kowalski's right to this immovable property] yesterday] caused...'

Moreover, when NEs events can be modified, this leads to the same inference patterns as those discussed in Davidson 1980 as an argument for his underlying quantification over events analysis.

Thus, I conclude that the restricted modification possibilities displayed by NEs should not be held against them.

Are There Negative Events?

Can NEs be events, or are there only negative states? The popular view is that, to the extent that negated clauses assert the existence of an eventuality at all, they may assert only the existence of states, or-more generally-duratives, i.e., states or processes; see, e.g., Moens 1987, Asher 1993, Verkuyl 1993, de Swart 1996, de Swart and Molendijk 1998.

However, there is a growing body of evidence that NEs may also be events. One argument, provided by de Swart and Molendijk 1998, is that negated clauses may move forward reference time in discourse, which is a sign that they may introduce events, see (27) above (and endnote 4). Another argument is that negated clauses may occur in the context What happened (next) was $X$, see the 
contrast between (28) above and (36) below.

*What happened next was that John loved Mary / that John was running.

Moreover, if the perfective vs. imperfective grammatical distinction in Polish reflects the event vs. durative semantic dichotomy (as it seems to do), then the negated gerunds in (21a), (30), (34) and (35) above, as well as in (i) in endnote 2, probably refer to negative events. Finally, if, as the contrast between (37)-(38) below suggests, pseudoclefts may embed events, but not states, then (39) also seems to involve a NE.

(37) What John did next was fall in love with Mary.

(38) *What John did next was love Mary.

(39) What the president did that caused such an uproar was not tell the truth.

Thus, it seems relatively clear that negated clauses may assert the existence of events, not just states, although it is perhaps an open analytical question whether these events are asserted directly or, say, coerced from states as de Swart and Molendijk 1998 would have it.

Metaphysical Status of Negative Eventualities

Once we accept NEs as first-class linguistic objects, the question arises whether they belong only to natural language metaphysics, or also to real world metaphysics (Bach 1981, Asher 1993).

One case where language makes a distinction apparently not reflected in the real world is aspect: the same real world event may be described as belonging to different aspectual classes, e.g., Peter was doing the washing up vs. Peter washed the dishes (Asher 1993), or eating a pint of ice cream vs. eating ice cream (Krifka 1992). Another example may be buying and selling. As discussed by Parsons 1990, p.84, these verbs, when used for describing the same situation, refer to two different events within the natural language metaphysics; this is because, e.g., the sentence Kim bought the tricycle from Sheehan with his (Kim's) MasterCard does not say the same as Sheehan sold the tricycle to Kim with his (Kim's) MasterCard. And yet, it makes sense to say that two different natural language events, described with buy or with sell, are mapped to the same real world event.

All the arguments for NEs given above are arguments for NEs qua citizens of natural language metaphysics. I see no arguments for positing a separate real world category of negative eventualities.

\section{Negative Eventualities and Negative Concord}

The previous section established the existence of negative eventualities, states as well as events. In this and the following section, I will present some evidence that 
NEs play an important role in the grammar, namely, that they take part in Negative Concord and that they bear on the ambiguity of negated polar interrogatives.

By Negative Concord (NC), I mean a phenomenon consisting in two or more negative constituents jointly expressing a single negation meaning, where a negative constituent is a constituent which may (alone) express (sentential) negation. (Note that NC is different from NPI-licensing; NPIs do not alone express sentential negation.) For example, in Polish, nie 'not' and nikt/nikomu 'nobody-NOM/DAT' are negative constituents, as shown in (40)-(42).

shows that their coocurrence leads to a single negation meaning.

(40) Janek nie pomógł Tomkowi.

John-NOM not helped Tom-DAT

'John didn't help Tom.'

(41) Kto pomógł Tomkowi? Nikt.

who-NOM helped Tom-DAT nobody-NOM

'Who helped Tom? Nobody.'

(42) Komu pomógł Janek? Nikomu.

whom-DAT helped John-NOM nobody-DAT

'Whom did John help? Nobody.'

(43) Nikt*(nie) pomógł nikomu.

nobody-NOM not helped nobody-DAT

'Nobody helped anybody.'

Negative pronouns such as nikt, nigdy 'never', etc., are called $n$-words (Laka 1990). The main question that analyses of NC try to answer is what licenses $n$-words. There are two main classes of approaches:

- syntactic approaches, e.g., Progovac 1988, 1994 (n-words as anaphors), Laka 1990, Zanuttini 1991, Haegeman and Zanuttini 1991, 1996, Haegeman 1995 ( $n$-words licensed by an operator in / the head of the $\Sigma \mathrm{P} / \mathrm{NegP}$ ), Przepiórkowski and Kupść 1997a,b,c (n-words licensed long-distance by a morphosyntactic feature);

- entailment approaches (extending Ladusaw's 1980 work on NPIs), e.g., Progovac 1993, van der Wouden and Zwarts 1993, van der Wouden 1994, Dowty 1994 (downward / upward entailment, antimorphicity, antiadditivity), Giannakidou 1997, 1998 (antiveridicality).

Below, I will present some arguments for a different kind of approach, i.e.:

- eventuality approaches: Tovena 1996a,b (sentential negation and $n$-word jointly negate the existence of an event), Przepiórkowski 1999 and Przepiórkowski and Kupść 1999 ( $n$-words licensed by NEs).

In Polish, $n$-words are licensed when they are eventuality-level dependents, or are within such dependents (subject to additional syntactic constraints; see 
Przepiórkowski and Kupść 1999), but not when they are within other dependents. Examples (43)-(46) show licensing of eventuality-level dependents (arguments, temporal and locative modifiers, instrumental modifiers, and manner modifiers, respectively), while (47)-(48) show the unacceptability of $n$-words within some non-eventuality-level modifiers.

(44) Nigdy / o żadnej porze / nigdzie / w żadnym miejscu tego nie robiłem. never / at no time / nowhere / at no place this not did-1.SG.MASC 'I haven't done it ever / at any time / anywhere / at any place.'

(45) Nie zrobisz tego żadnym młotkiem / niczym. not do-2.SG this no-INS hammer-INS / nothing-INS 'You won't do this with any hammer / with anything.'

(46) Nie zrobisz tego w żaden sposób / nijak. not do-2.SG this in no way / nohow 'You cannot do that any way.'

(47) *Według/zdaniem żadnego rosyjskiego polityka, Polska nie powinna according to no Russian politician Poland not should przystapić do NATO. join to NATO 'According to no Russian politician should Poland join NATO.' (putative)

*Nie zrobiłem tego dzięki nikomu. not did-1.SG.MASC this thanks nobody-DAT

'I haven't done this thanks to anybody.' (putative)

(48) is particularly interesting here because it shows that the licensing factor is not simply the scope of negation; as (49) below shows, the position occupied by nikomu in (48) may be in the scope of negation, and yet (48) is ungrammatical. Thus, the data in (48)-(49) posit a real challenge for those theories which link licensing of $n$-words to the scope of a negative operator, and, on the other hand, support the eventuality-level approach.

Nie zrobiłem tego dzięki Jankowi, tylko dzięki Tomkowi. not did-1.SG.MASC this thanks John-DAT only thanks Tom-DAT 'I haven't done this thanks to John, only thanks to Tom.'

Another argument for our claim that NEs may play the licensing role in NC will be given in the next section.

\section{Negative Eventualities and Negated Yes/No Interrogatives}

\subsection{Ambiguity of Negated Yes/No Interrogatives}

According to the standard answer-theoretic view (dating back to Hamblin 1958), the semantics of negated yes/no interrogatives is the same as the semantics of their non-negated counterparts; see Groenendijk and Stokhof 1997 (and references 
therein) for a recent reappraisal. Any apparent differences are relegated to pragmatics. Here, I would like to challenge this view on the basis of the observation that a robust ambiguity of negated yes/no interrogatives is reported for : various languages, and that this ambiguity bears on Negative Concord, a syntactico-semantic, not pragmatic, phenomenon.

The relevant ambiguity in German is discussed (in pragmatic terms) by Meibauer 1990, who gives the following example. ${ }^{5}$

(50) Ich frage mich, ob Fritz (wirklich) nicht kommt.

I ask myself if Fritz (really) not comes

'I wonder whether Fritz is coming.'

'I wonder whether Fritz is (really) not coming.'

On one reading, negation is neutralized, as answer-theoretic theories predict, but on the other reading, forced by adding wirklich 'really' or by putting some stress on nicht 'not', the question is understood as asking for confirmation of an occurrence of a negative eventuality.

It Italian, as is well known, sentential negation may be expressed either by the negative marker non, or by a pre-verbal $n$-word. Interestingly, both lead to ambiguity in polar interrogatives, which suggests that this is a general property of sentential negation, and not of, say, a lexical item (see Przepiórkowski 1999).

(51) Voleva sapere se nessuno ha telefonato.

wanted-3.SG know if nobody AUX phoned

'(S)he wanted to know whether anybody phoned.'

'(S)he wanted to know whether nobody phoned.'

(52) Voleva sapere se Mario (veramente) non ha telefonato.

wanted-3.SG know if Mario (really) not AUX phoned

'(S)he wanted to know whether Mario had phoned.'

'(S)he wanted to know whether Mario (really) hadn't phoned.'

Again, just as in German, a negated yes/no interrogative may mean, roughly, either is $\left(n^{\prime} t\right)$ it the case that $\mathrm{p}$ ?, in which negation is neutralized, or is it the case that not $\mathrm{p}$ ? forced, again as in German, by adding 'really' or by putting some stress on the negative element.

Further, the same ambiguity surfaces in Slavic languages; but here the situation is even more interesting because $n$-words may occur in negated yes/no interrogatives only on the 'confirmation of the occurrence of a NE' reading, not on the 'neutralized negation' reading; see the Serbo-Croatian data (drawn from Progovac 1994 and Brown and Franks 1995) below, in which zar 'really' disambiguates the question (again!) to the former reading, and the complementizer $d a$ seems to force the latter reading, as the (original) glosses show.

(53) Zar ne zna $n i(t) k o$ od vas kako se to radi?

really not know nobody of you how Refl this does

'Can it be that none of you know how this is done?' 
Da $n e$ zna *ni(t)ko / i(t)ko od vas kako se to radi?

Comp not know nobody / anybody of you how Refl this does

'Does any one of you know how this is done?'

As (53)-(54) show, only on the negative eventuality reading is the $n$-word $n i(t) k o$ allowed; on the other reading, the NPI $i(t) k o$ must be used instead. This contrast seems to confirm in an interesting way the claim of the previous section, i.e., that NEs may license $n$-words in NC languages. Moreover, such interaction of NC and polar interrogatives seems to pose a serious challenge for entailment-based approaches to $\mathrm{NC}$, because of the ill-understood (and controversial) nature of entailment properties of questions (as opposed to entailment of propositions).

Similar data, leading to similar conclusions, are known for Russian (see Brown and Franks 1995 for an extensive discussion and for a syntactic GB analysis) and for Polish (see Przepiórkowski and Kupść 1999 for an HPSG analysis semantically compatible with present considerations).

Interestingly, the same contrast is also present in Italian, although in a slightly concealed way. In this language, $n$-words are licensed not only by negation, but also by questionhood and other environments, so it is not clear what exactly licenses nessuno in (51). However, as noted by Zanuttini 1991, as soon as an $n$-word is modified by quasi 'almost', it may be licensed only by negation (or negative eventuality, if our claim is right). This means that adding quasi to (51) should make the 'neutralized negation' reading unavailable. This prediction is confirmed:

(55) Voleva sapere se quasi nessuno ha telefonato. wanted-3.SG know if almost nobody AUX phoned

*'(S)he wanted to know whether almost anybody phoned.'

?'(S)he wanted to know whether almost nobody phoned. ${ }^{\prime 6}$

This interaction of $\mathrm{NC}$ with the ambiguity of negated yes no interrogatives strongly suggest that this ambiguity is not just some ephemeral pragmatic effect; in Slavic, as well as in Italian, Negative Concord is always analysed as a (syntactico)semantic phenomenon, apparently unaffected by pragmatics.

\subsection{A Situation Semantics Analysis ${ }^{7}$}

Since the aim of this section is to sketch a Situation Semantics analysis of the ambiguity of negated yes/no interrogatives, and the intuition we want to capture is that one of the readings involves a NE, we should first decide what Situation Semantic constructs correspond to our intuition of eventualities. Although Barwise and Perry 1983 seem to equate events and situations, there are actually at least four possibilities, reflecting different views on whether eventualities are atomic or cumulative, and whether they are abstract linguistic (theoretic) entities, or real world objects:

- cumulative and real world $\rightarrow$ situations;

- cumulative and abstract $\rightarrow$ infons; 
- atomic and real world $\rightarrow$ minimal/atomic situations (Moore 1993);

- atomic and abstract $\rightarrow$ basic infons.

Since I am concerned here with eventualities as atomic and abstract objects, I will : assume that, in Situation Semantics, they are represented by basic infons.

Now, my claim is that the observed ambiguity of negation in yes/no questions is a reflex of a more general ambiguity of negation assumed within Situation Semantics (see, especially, Barwise and Etchemendy 1987, and Cooper 1997). More specifically, assuming that (56) is a representation of John saw Mary (see Devlin 1991 for notation and for treating the 'support' relation ' $\mid=$ ' on par with other relations), then (57)-(58) will be representations of the two readings of John did not see Mary. ${ }^{8}$

$$
\begin{aligned}
& <<\mid=, \mathrm{s}, \quad<<\text { see, J, M; }+>>\text {; }+>>\text {, read as: } \\
& \text { 'Situation s supports the state of affairs (i.e., infon) }<<\text { see, J, M; + >>.' } \\
& <<\mid=, \mathrm{s}, \quad<<\text { see, J, M; }->>\text {; }+>>\quad \text { (eventuality negation) } \\
& \text { 'Situation s supports the state of affairs }<<\text { see, J, M; }->>\text {.' } \\
& <<\mid=, \mathrm{s}, \quad<<\text { see, J, M; }+>>\text {; }->>\quad \text { (propositional negation) } \\
& \text { 'Situation s does not support the state of affairs }<<\text { see, J, M; }+>>\text {.' }
\end{aligned}
$$

Note that, because of my understanding of eventualities as abstract and atomic, I take the basic infons $<<$ see, J, M; $+>>$ and $<<$ see, J, M; $->>$ to represent, respectively, positive and negative eventualities.

I extend the notation of (56)-(58) to questions (compare Ginzburg 1992, $1995)$ and assume that (59) is the Situation Semantics representation of Did John see Mary?, while (60)-(61) are representations of Didn't John see Mary?.

$$
\begin{aligned}
& <<\text { ?, s, }<<\text { see, J, M; }+>>\text {; }+>> \\
& \text { 'Does situation s support the state of affairs }<<\text { see, J, M; }+>>\text { ?' } \\
& <<\text { ?, s, }<<\text { see, J, M; }->>\text {; }+>>\quad \text { (eventuality negation) } \\
& \text { 'Does situation s support the state of affairs }<<\text { see, J, M; }->>\text { ?' } \\
& <<\text { ?, s, }<<\text { see, J, M; }+>>\text {; }->>\quad \text { (propositional negation) } \\
& \text { 'Does situation s not support the state of affairs }<<\text { see, J, M; }+>>\text { ?' }
\end{aligned}
$$

Now, given these representations, natural questions that arise are: Why is propositional negation neutralized in yes/no interrogatives?, and, a more general question, Why does the ambiguity of sentential negation surface in interrogatives, but not in declaratives?

The answer to the first question is standard: assuming the answer-theoretic approach to questions, the meaning of (61), involving propositional negation, is the same as the meaning of (59), i.e., the set of possible answers ' $S$ ituation $\mathrm{s}$ supports $<<$ see, J, M; $+>>$ ', 'Situation s does not support $<<$ see, J, M; $+>>$ '\}. Of course, this identity of meanings (qua possible answers) does not carry over to (60), whose answer-theoretical meaning is different, namely, \{'Situation s supports $<$ see, J, M; - >>', 'Situation s does not support $<<$ see, J, M; $->>$ '\}.

The second question is less trivial. We will first answer the second part of this question (i.e., Why does the ambiguity of sentential negation not surface in 
declaratives?), and then the first part (Why does it surface in yes/no interrogatives?).

Note first that (57) and (58) have genuinely different meanings: although (58) follows from (57) because of the coherence of situations, (57) does not follow from (58) because situations are in general partial (i.e., it is not the case that for each situation s and each state of affairs $\sigma$, s supports $\sigma$ or its dual). However, as emphasised by Devlin 1991, pp.265-267, 289-290, co-operative use of utterances "places on the speaker an obligation that the described situation as understood by the listener... is sufficiently rich to decide the relevant issue..." In other words, although situations are partial, described situations are normally complete relative to the infons used to describe them (Devlin 1991, p.267). This means that (57) and (58) are normally synonymous, by the way we talk about situations.

If so, why then does the ambiguity of negation surface in polar interrogative clauses at all? Relative completeness of every-day situations would imply that the two meanings of (60)-(61) are also equivalent. I believe that this conclusion is actually true, i.e., that negated yes/no interrogatives are ambiguous, but the two meanings are truth-conditionally equivalent. ${ }^{9}$ This actually reflects the intuitions of native speakers, who-when faced with negated yes/no interrogatives as those in \$3.1.- - usually report that these interrogatives are ambiguous between a 'positive' reading, the same as that of the corresponding positive interrogative, and a 'negative' reading, which licenses $n$-words, but they are at loss when asked to pinpoint the difference. ${ }^{10}$

\section{Summary}

Here are the main results of this paper:

1) negated clauses, negated deverbal nominals, etc., may express eventualities, states as well as events, just as their non-negated counterparts do; in other words, negative eventualities exist;

2) negative eventualities seem to play an important role in the grammar:

- they play the licensing role in Negative Concord;

- negated interrogatives are visibly ambiguous, with one of the readings involving negative eventualities;

3) a rather natural analysis of this ambiguity may be formulated within Situation Semantics.

I realize that the results of this paper open many new questions, including those about the exact properties of NEs, and about the place of eventualities in Situation Semantics. I would like to hope that this paper will stimulate future research on these issues.

\section{Endnotes}

* I wish to thank the following people for their comments on parts of the material presented here and/or for discussions: Joanna Błaszczak, Mike Calcagno, 
Graham Katz, Anastasia Giannakidou, Jonathan Ginzburg, Manfred Sailer, Henriëtte de Swart, and Matthew Whelpton, as well as audiences at Tübingen (November 1998), Utrecht (Going Romance, December 1998), and Santa Cruz : (SALT 9, February 1999). None of them should be blamed for any remaining flaws. I am also grateful to Mike Calcagno, Tom Cornell, Paul King and Gerald Penn for their help with the English data.

Since the publisher of these proceedings does not accept LaTeX or PostScript, this paper had to be formatted in an inferior word processor, i.e., Word for Windows. I take only partial responsibility for the final typesetting.

Contexts such as $X$ is true and believe $X$ are propositional contexts, while indicate $X$ and show $X$ are supposed to be factual contexts; see Asher 1993 for details.

2 Of course, NEs can be referred to also by other kinds of deverbal nominals, cf. the attested Polish example below and its English translation.

(i) Wczorajsze niepodpisanie ustawy przez prezydenta było wydarzeniem, yesterday-ADJ not-signing-PERF bill by president was event które zdominowało wiadomości dnia. which dominated news day '[[The president's not signing the bill] yesterday] was an event which dominated the day's news.'

That the negated nominal in this particular case refers to an eventuality is suggested by the fact that it is temporally modified (see the main text), and perhaps also by the use of wydarzeniem 'event'. The point I am making is that such deverbal nominals can also be used to refer to other kinds of abstract entities, so the sheer possibility of negating them does not yet constitute evidence for NEs.

3 Note, however, that Asher 1993 distinguishes semantic arguments of perception verbs, which he calls (after Barwise and Perry 1983) situations, from eventualities.

$4 \quad$ According to de Swart and Molendijk 1998, negated sentences may express negative events only indirectly, i.e., these negative events are coerced from negative states via a general state-to-event coercion mechanism (see de Swart 1998).

5 See also Borillo 1979 on French, not discussed here for lack of space.

The question mark in front of this reading means that, although some speakers find the sentence fully acceptable on this reading (and, hence, the contrast between the readings clear), others consider it not fully acceptable (but clearly better than the other reading), while some find neither reading acceptable.

$7 \quad$ For space reasons, I have to be concise here, so this section presupposes some knowledge of Situation Semantics (e.g., Devlin 1991).

$8 \quad$ Barwise and Etchemendy 1987 call propositional negation 'denial', and Cooper 1997 calls eventuality negation 'infonic negation'.

9 Of course, saying that there is a semantic non-truth-conditional ambiguity makes sense only in a theory that goes beyond truth conditions in search for meaning, such as Situation Semantics. 
$10 \quad$ See also Przepiórkowski 1999 and Przepiórkowski and Kupść 1999 for a syntactico-semantic analysis of Negative Concord in Italian and in Polish, embedding the analysis of negated yes/no interrogatives presented here.

\section{References}

Asher, N. 1993. Reference to Abstract Objects in Discourse. Kluwer, Dordrecht. Bach, E. 1981. On time, tense, and aspect: An essay in English metaphysics. In P. Cole, editor, Radical Pragmatics, pp.62-81, Academic Press, New York.

Barwise, J. and Etchemendy, J. 1987. The Liar: An Essay on Truth and Circularity. Oxford University Press, New York and Oxford.

Barwise, J. and Perry, J. 1983. Situations and Attitudes. The MIT Press, Cambridge, Mass.

Bennett, J. 1988. Events and their Names. Hackett Press, Indianapolis.

Borillo, A. 1979. La négation et l'orientation de la demande de confirmation. Language française, 44, 27-41.

Brown, S. and Franks, S. 1995. Asymmetries in the scope of Russian negation. Journal of Slavic Linguistics, 3, 239-287.

Cooper, R. 1997. Austinian propositions, Davidsonian events and perception complements. In J. Ginzburg, Z. Khasidashvili, C. Vogel, J.-J. Lévy, and E. Vallduví, editors, The Tbilisi Symposium on Language, Logic and Computation: Selected Papers. CSLI Publications, Stanford.

Davidson, D. 1980. Essays on Actions and Events. Clarendon Press, Oxford.

Does, J. v. d. 1991. A generalized quantifier logic for naked infinitives. Linguistics and Philosophy, 14, 241-294.

Dowty, D. 1994. The role of negative polarity and concord marking in natural language reasoning. In Proceedings of SALT 4, Cornell University Press, Ithaca, NY.

Giannakidou, A. 1997. The Landscape of Polarity Items. Ph.D. thesis, Rijksuniversiteit Groningen.

Giannakidou, A. 1998. Polarity Sensitivity as Non)Veridical Dependency. Benjamins, Amsterdam and Philadelphia.

Ginzburg, J. 1992. Questions, Queries and Facts: A Semantics and Pragmatics for Interrogatives. Ph.D. thesis, Stanford University.

Ginzburg, J. 1995. Resolving questions I \& II. Linguistics and Philosophy, 18, 459-527, 567-609.

Groenendijk, J. and Stokhof, M. 1997. Questions. In J. van Benthem and A. ter Meulen, editors, Handbook of Logic and Language, pp.1055-1124, Elsevier and The MIT Press, Amsterdam and Cambridge, Mass.

Haegeman, L. 1995. The Syntax of Negation. Cambridge University Press, Cambridge.

Haegeman, L. and Zanuttini, R. 1991. Negative heads and the Neg Criterion. The Linguistic Review, 8, 233-251.

Haegeman, L. and Zanuttini, R. 1996. Negative concord in West Flemish. In A. Belletti and L. Rizzi, editors, Parameters and Functional Heads, pp.117- 
179. Oxford University Press, New York.

Hamblin, C. L. 1958. Questions. Australasian Journal of Philosophy, 36, 159168.

Higginbotham, J. 1983. The logic of perceptual reports: An extensional alternative to Situation Semantics. The Journal of Philosophy, 80, 100-127.

Higginbotham, J. 1996a. On events in linguistic semantics. Unpublished manuscript, version of 25 June 1997, Oxford University.

Higginbotham, J. 1996b. Perceptual reports revisited. Unpublished manuscript, version of 27 November, 1996, Oxford University.

Kamp, H. and Reyle, U. 1993. From Discourse to Logic. Kluwer, Dordrecht.

Krifka, M. 1992. Thematic relations as links between nominal reference and temporal constitution. In I. A. Sag and A. Szabolcsi, editors, Lexical Matters, CSLI Publications, Stanford.

Ladusaw, W. 1980. Polarity Sensitivity as Inherent Scope Relations. Garland, New York and London.

Laka, I. 1990. Negation in Syntax: On the Nature of Functional Categories and Projections. Ph.D. thesis, Massachusetts Institute of Technology.

Meibauer, J. 1990. Sentence mood, lexical categorical filling, and nonpropositional nicht in German. Linguistische Berichte, 130, 441-465.

Moens, M. 1987. Tense, Aspect and Temporal Reference. Ph.D. thesis, University of Edinburgh.

Moore, R. C. 1993. Events, situations, and adverbs. In M. Bates, editor, Challenges in Natural Language Processing, pp.135-145, Cambridge University Press, Cambridge.

Parsons, T. 1990. Events in the Semantics of English: A Study in Subatomic Semantics. The MIT Press, Cambridge, Mass.

Progovac, L. 1988. A Binding Approach to Polarity Sensitivity. Ph.D. thesis, University of Southern California, Los Angeles.

Progovac, L. 1993. Negative polarity: Entailment and binding. Linguistics and Philosophy, 16, 149-180.

Progovac, L. 1994. Negative and Positive Polarity. Cambridge University Press, Cambridge.

Przepiórkowski, A. 1999. Negative polarity questions and Italian negative concord. In V. Kordoni, editor, Tübingen Studies in Head-Driven Phrase Structure Grammar, Arbeitspapiere des Sonderforschungsbereichs 340, Bericht Nr. 132, Seminar für Sprachwissenschaft, Universität Tübingen.

Przepiórkowski, A. and Kupść, A. 1997a. Negative concord in Polish. Report 828, Institute of Computer Science, Polish Academy of Sciences.

Przepiórkowski, A. and Kupść, A. 1997b. Unbounded negative concord in Polish: A lexicalist HPSG approach. In J. Landsbergen, J. Odijk, K. van Deemter, and G. V. van Zanten, editors, Computational Linguistics in the Netherlands 1996, pp.129-143, Eindhoven.

Przepiórkowski, A. and Kupść, A. 1997c. Verbal negation and complex predicate formation in Polish. In R. C. Blight and M. J. Moosally, editors, Proceedings of the 1997 Texas Linguistic Society Conference on the Syntax and Semantics of Predication, volume 38 of Texas Linguistic 
Forum, pp.247-261, Austin, Texas.

Przepiórkowski, A. and Kupść, A. 1999. Eventuality negation and negative concord in Polish and Italian. In R. D. Borsley and A. Przepiórkowski, editors, Slavic in HPSG. CSLI Publications, Stanford.

Stockwell, R., Schachter, P., and Partee, B. 1973. The Major Structures of English. Holt, Rinehart \& Winston, Inc., New York.

de Swart, H. 1996. Meaning and use of not ...until. Journal of Semantics, 13, 221263.

de Swart, H. 1998. Aspect shift and coercion. Natural Language and Linguistic Theory, 16, 347-385.

de Swart, H. and Molendijk, A. 1998. Negation and the temporal structure of narrative discourse. Unpublished manuscript, August 20, 1998, Utrecht University and University of Groningen.

Thompson, J. J. 1977. Acts and Other Events. Cornell University Press, Ithaca, NY.

Tovena, L. M. 1996a. Bringing events to bear on the study of negative concord marking. GenGenP, 4, 60-79.

Tovena, L. M. 1996b. Studies in polarity sensitivity. Ph.D. thesis, University of Edinburgh.

Vendler, Z. 1967. Linguistics in Philosophy. Cornell University Press, Ithaca, NY.

Verkuyl, H. 1993. The Theory of Aspectuality: The Interaction Between Temporal and Atemporal Structure. Cambridge University Press, Cambridge.

van der Wouden, T. 1994. Negative Contexts. Ph.D. thesis, University of Groningen.

van der Wouden, T. and Zwarts, F. 1993. A semantic analysis of negative concord. in U. Lahiri and A. Z. Wyner, editors, Proceedings of SALT 3, pp.202219, Cornell University Press, Ithaca, NY.

Zanuttini, R. 1991. Syntactic Properties of Sentential Negation. A Comparative Study of Romance Languages. Ph.D. thesis, University of Pennsylvania.

Adam Przepiórkowski

Polish Academy of Sciences

Institute of Computer Science

ul. J. Ordona 21

01-237 Warszawa

Poland

email: adamp@ipipan.waw.pl

URL: http://www.ipipan.waw.pl/mmgroup/ap.html 